\title{
Design of RIVAL (Cari Travel Malang) Application as One Stop App Solution for Travel Reservation in Malang
}

\author{
Novita Rosyida*, Agung Dwi Saputra \\ Program of Vocational Education, University of Brawijaya, Malang, Indonesia
}

\begin{abstract}
Reservations can be interpreted as order transaction for place, ticket, or goods between business owners or service providers with consumers. In Malang, people especially reserved some travel reservations manually. They reserve the travel by phone to the travel customer service or came to the travel office. Based on the problem, the author made an application called RIVAL (Cari Travel Malang) as a one-stop app solution for travel reservations in Malang that runs on a mobile platform with an Android operating system. In this design phase, the application is still local, runs on the local server developer, and runs online for application testing to several people. With this application, it is expected that travel reservations that initially carried out manually by coming to the service provider, now it can be done anywhere. The results of the implementation and testing were given to eight respondents with several different versions of the Android operating system, namely Android Lollipop, Marshmallow, Oreo, and Pie. It was found that the application runs well without any UI constraints or main functions in the application with additional data response obtained from the test questionnaire form that the application is easy to understand from the user interface, provided information, and easy to use. With this application, it is expected travel reservation in Malang can be done easily and efficiently.
\end{abstract}

Keywords: Mobile Application, Reservation, Travel application.

\section{INTRODUCTION}

Business in the $4^{\text {th }}$ industrial revolution era is a recent change that concerns in technological development. It includes cyber-physical organization, the internet of matter or internet of thing, cloud technology, and cognitive technology [1]. The newest technical growth in the travel industry called an Automated Booking System (ARS) that assisted travel agents to manage an online booking system. The general booking system offered a single direction of operation to book travel products such as car rental or travel reservations using online bookings. The current beginning in the travel industry not only offered many benefits to the travel organization but also managed to offer cost-effectively and simple travel item to the customer.

Smartphones have continued to grow in popularity within the Indonesian citizen over the past few years, particularly with older citizens, creating a need for universal usability within the applications that these devices contain. Mobile Application Development refers to the process of making application software for hand held devices such as mobile phones and Personal Digital Assistants [2,3].

Through the usage of mobile apps, the user is provided with various features that will enable

\footnotetext{
* Correspondence address:

Novita Rosyida

Email : novitarosyida@ub.ac.id

Address : Program of Vocational Education, University of Brawijaya, Veteran Malang, 65145.
}

him to fulfill all his needs and much more. Apps should be interactive to the users.

Malang is one of the second largest cities in East Java after Surabaya. Malang has been known as one of the hot sport for tourism attraction in East Java. Tourism destination was distribute from coastal area to mountian area. Bromo Tengger Semeru is one of the most visited destination, in which tourism can access numerous natural attraction from Malang area $[4,5,6]$.

The relationship between tourism and transportation can be seen from the advancement of the tourism industry that can create a demand for transportation to meet needs, and the transportation facilities can encourage tourism progress [7]. Based on a survey conducted on several travel companies in Malang at the end of 2018, the travel booking system from Malang to Surabaya or surrounding cities conducted by the customer is still done manually. The customer comes to the office of travel service providers directly, or by calling customer service from the travel agent, then the travel agent will collect the customer data.

According to information obtained through www.similarweb.com, which is a website providing a comparative analysis of the use of websites and applications in the world, at the end of 2018 the total access to online booking applications such as Traveloka in 1 month can reach 39.18 million, Tiket.com reaches 8.90 million, and Booking.com reached 3.97 million within one month [8]. A total of 70 percent of 
users prefers to order these services through the application rather than website. Data from similarweb.com shows the high public interest in online booking to reduce ineffective manual travel booking. So that in this research, we design the RIVAL (Cari Travel Area Malang) application as one solution for rent car and travel booking in Malang Area. RIVAL designed for Android-based smartphones because most people in Malang using Android smartphones.

\section{METHOD}

RIVAL application is an application designed to facilitate the user in searching and booking travel in the Malang area using an android application. The general description if RIVAL application is shown in Figure 1 . The stages of developing RIVAL applications are designing flow diagram/flowchart, designing database, designing $U I$ and $U X$, and functionality test of rival application.

Figure 1 shows the interaction between the user, RIVAL application, and database. To make a reservation, the user should open the application to choose departure and destination city. After that, they chose a departure date and number of passengers. The server will process the data that inputted by the user then give a response, which travels that available according to the data input from the user. Then the user chose the schedule from the server and chose the seat according to the availability of travel. The user fills the reservation form, then the reservation will process by the server, and the user gets confirmation from the server. The flowchart of the RIVAL application is shown in Figure 2.

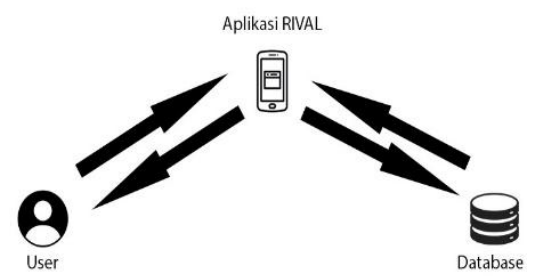

Figure 1. General Description of RIVAL Application

\section{Software requirement}

The software requirements to design and develop RIVAL application are:

- Android Studio Application version 3.3.1, is used as an IDE to built RIVAL application based on Android.

- Json Pojo Schema, as a tool to facilitate the conversion of JSON data format into GSON data format, so the data can be accessed by Java.

\section{Database Design}

The database design of the RIVAL application is using eight entities or tables, that are: user, company/travel agent, destination track, seats, city transfer, city, district, and schedule.Each entity is interrelated to run the system, if one of the entities removed, it will cause errors in the system because the data in each entity, is needed by other entities. The description of the database design is shown in Table 1.
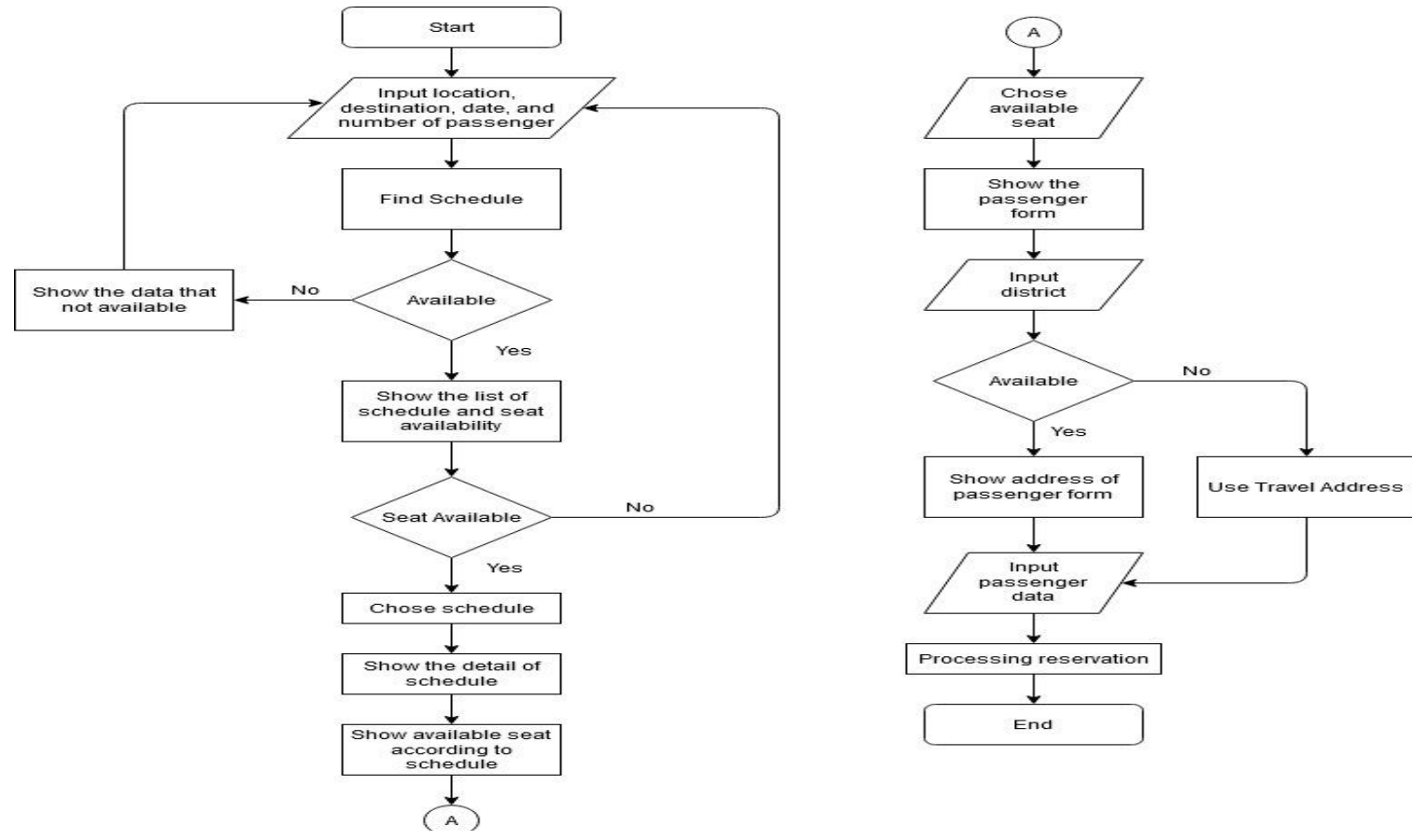

Figure 2. Flowchart of RIVAL Application 
Table 1. Database Design of Rival Application

\begin{tabular}{|c|c|c|}
\hline No & Entity & Description \\
\hline 1 & User & $\begin{array}{l}\text { The user table is used to save all user data who access this application. The columns are: id, } \\
\text { username, password, email, phone number, status, and cancel. }\end{array}$ \\
\hline 2 & Company/travel agent & $\begin{array}{l}\text { The company table is used to save all travel agent data registered in the RIVAL application. } \\
\text { The columns are: company_id, admin_id, name of travel agent, office_address, } \\
\text { phone_number. }\end{array}$ \\
\hline 3 & Destination & $\begin{array}{l}\text { The destination table is used to save the reservation data. The columns are: address_id, } \\
\text { destination_id, travel_id, passenger_id, seat, reservation_date, departure_date, pick up } \\
\text { address, destination address, name of passenger, phone number }\end{array}$ \\
\hline 4 & Seat & $\begin{array}{l}\text { The seat table is used to show seat data and seat availability on RIVAL Application. The } \\
\text { columns are: seat_id, destination_id, seat_status. }\end{array}$ \\
\hline 5 & City transfer & $\begin{array}{l}\text { City transfer is the city that passed by the travel according to the schedule that registered by } \\
\text { admin. The columns are: city transfer_id, destination_id, city_transfer, price. }\end{array}$ \\
\hline 6 & City & All destination city that registered by admin. The columns are: id_city, city. \\
\hline 7 & District & $\begin{array}{l}\text { Th district is the district that passedthrough by the travel that registered by admin. The } \\
\text { columns are: district_id, district. }\end{array}$ \\
\hline 8 & Schedule & $\begin{array}{l}\text { The schedule table shows the travel schedule that registered by admin. The columns are: } \\
\text { destination id, travel_id, city_id, distric_id, departure_city, departure_district, destination, } \\
\text { car_id, car_number, seat availability, start_date, end_date, travel status. }\end{array}$ \\
\hline
\end{tabular}

Table 2. Black-box Testing Scenario

\begin{tabular}{cll}
\hline No & Tested component & Detail of testing \\
\hline 1 & Login page & $\begin{array}{l}\text { Show login form } \\
\text { Run the login function }\end{array}$ \\
\hline 2 & Register page & $\begin{array}{l}\text { Show register form } \\
\text { Run the register function }\end{array}$ \\
\hline 3 & Main menu & $\begin{array}{l}\text { Show the reservation menu } \\
\text { Showing side menu }\end{array}$ \\
& & Run the finding schedule function \\
\hline 4 & Schedule page & She the departure schedule of travel \\
\hline 6 & Detail of schedule page & Show the timeline schedule \\
\hline 7 & Seat page & Show the empty seat and reserved seat \\
\hline 8 & Reservation form page & Show the district list \\
\hline 9 & List of reservation page & Show address filling form \\
\hline 10 & Historical page & Show the confirmation of reservation \\
\hline & & Show the list of active reservation \\
\hline
\end{tabular}

\section{Software Testing}

Software testing is very necessary to ensure the software or applications that made run according to the functionality, which is expected. A software developer or tester must prepare a special session to test programs that have been made so that the errors or deficiencies can be detected early and corrected immediately. Testing is a critical element of software quality assurance and is an inseparable part of the cycle live software development as analysis, design, and coding [9]. The software testing that we use is alpha testing and beta testing.

Alpha Testing is a type of software testing that performed to identify bugs before releasing the product to real users or to the public. The method of alpha testing is using black-box testing. Black-Box Testing is testing focuses on functional specifications from the software. A tester can define a collection of input conditions and testing the specifications' functional program [10]. The testing scenario is shown in Table 2.

Beta Testing performed by real users of the software application in a real environment. Beta testing is one of the types of User Acceptance Testing. Beta testing is a test conducted to know the extent of system performance, whether it meets expectations or not [11]. For beta testing, data collected through questionnaires from respondents or potential users of the system. The respondent evaluation will be count from the percentage of score or value given by respondents (Table 3 ).

$$
P=\frac{(Q x S)}{\text { Ideal Score }} x 100 \%
$$

Description:

$\mathrm{P} \quad=$ percentage

Q $\quad=$ Number of user

$\mathrm{S}=$ Score

Ideal Score $=$ Highest score $\mathrm{x}$ number of user 
Table 3. Percentage of testing

\begin{tabular}{ccc}
\hline No & Percentage (\%) & Result \\
\hline 1 & $0-20$ & Very difficult \\
2 & $20-40$ & Quite difficult/not help \\
3 & $40-60$ & Neutral \\
4 & $60-80$ & Quite easy/quite helpful \\
5 & $80-100$ & Very easy/very helpful \\
\hline
\end{tabular}

\section{RESULT AND DISCUSSION}

\section{Rival Application Display}

UI (User Interface) is a bridge between the user (user) with the application through a visual display of shapes, colors, writing (typography) to create interesting interactions of an application. Whereas UX (User Experience) is the experience gained by users when using an application. So that in making the UI/UX focused on three main basic colors, there are blue, white, and orange, with a small number of color combinations it is expected that users have experience using the application easily. The login and register form of Rival Application showed in Figure 3. It is the first page when we open the RIVAL application and used it to access the reservation feature of RIVAL Application.

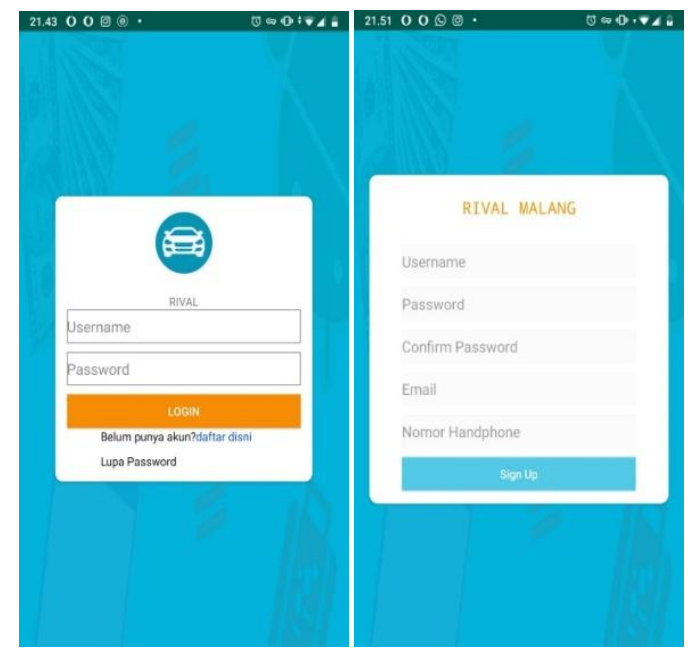

Figure 3. Login and Register Form of Rival Application

The home menu shows the searching schedule form with departure location, destination, date of departure, and the total of passengers. The list of schedule forms shows the schedule of travel that available, the agent of travel, type of car, and price. The detailed schedule form shows the schedule selected by the passenger with the travel agent, departure time, and total of available seats. The list order form shows the active reservation and the data of passengers who succeeded in doing the reservation. All UI/UX that has been designed and developed will be tested to know the functionality of the application.

\section{Testing Result}

Alpha Testing

Alpha testing has been done based on the black-box method (Table 2). There are ten components of the application page (UI/UX) that tested using the black-box method.The components are login page, registered page, main menu page, schedule page, detail of schedule page, seat page, reservation form page, confirmation page, list of reservation, and historical page. The result of black-box testing showed in Table 4. Based on the alpha testing with the testing scenario in Table 4, we can conclude that the RIVAL application work properly, but the development of aplication always needed.

\section{Beta Testing}

In beta testing, the application tested to eight respondents with a different version of the Android application. All respondents tried the RIVAL application and gave an evaluation of the application from the questionnaire. Then the evaluation made from the percentage value for each question. The results of beta testing are shown below.

Question 1. The user interface of RIVAL application is easy to understand.

Table 5. Result of Question 1

\begin{tabular}{|c|c|c|c|c|c|}
\hline Question & No & Information & Score & $\mathbf{Q}$ & $\mathbf{S}$ \\
\hline \multirow[t]{5}{*}{1} & 1 & Very easy & 5 & 4 & 20 \\
\hline & 2 & Quite easy & 4 & 4 & 16 \\
\hline & 3 & Neutral & 3 & 0 & 0 \\
\hline & 4 & Quite difficult & 2 & 0 & 0 \\
\hline & 5 & Very difficult & 1 & 0 & 0 \\
\hline Total & & & & 8 & 36 \\
\hline
\end{tabular}

Intepretation:the UI display of the RIVAL application is very easy to understand.

Question 2. The information of travel reservation using RIVAL application is easy to understand.

Table 6. Result of Question 2

\begin{tabular}{|c|c|c|c|c|c|}
\hline Question & No & Information & Score & $\mathbf{Q}$ & $\mathbf{s}$ \\
\hline \multirow[t]{5}{*}{2} & 1 & Very easy & 5 & 1 & 5 \\
\hline & 2 & Quite easy & 4 & 5 & 20 \\
\hline & 3 & Neutral & 3 & 2 & 6 \\
\hline & 4 & Quite difficult & 2 & 0 & 0 \\
\hline & 5 & Very difficult & 1 & 0 & 0 \\
\hline Total & & & & 8 & 31 \\
\hline
\end{tabular}

Intepretation:the information of travel reservation using RIVAL application is quite easy to understand. 
Table 4. Result of Alpha Testing Using Black Box Method

\begin{tabular}{|c|c|c|c|}
\hline Component & Testing Scenario & Expected Result & Test Result \\
\hline \multirow[t]{2}{*}{ 1. Login page } & Open RIVAL Application & Show the login form & {$[\sqrt{ }]$ Success[ ] Fail } \\
\hline & $\begin{array}{l}\text { Fill the login data and press login } \\
\text { button }\end{array}$ & Login success and go to main menu & {$[\checkmark]$ Success[ ] Fail } \\
\hline \multirow[t]{2}{*}{ 2. Register page } & Choose register page & Show register form & {$[\checkmark$ ] Success[ ] Fail } \\
\hline & $\begin{array}{l}\text { Fill register data and press } \\
\text { register button }\end{array}$ & $\begin{array}{l}\text { Register success and go to login } \\
\text { page }\end{array}$ & {$[\checkmark]$ Success[ ] Fail } \\
\hline \multirow[t]{3}{*}{ 3. Main menu } & Enter the main menu after login & $\begin{array}{l}\text { Show the home page with schedule } \\
\text { searching menu }\end{array}$ & {$[\checkmark]$ Success[ ] Fail } \\
\hline & Press the navigation bar & Show the side menu & {$[\checkmark$ ] Success[ ] Fail } \\
\hline & $\begin{array}{l}\text { Filling data in searching schedule } \\
\text { menu and press searching button }\end{array}$ & $\begin{array}{l}\text { Searching menu success and go to } \\
\text { schedule page }\end{array}$ & {$[\checkmark]$ Success[ ] Fail } \\
\hline 4. Schedule page & $\begin{array}{l}\text { Filling data in searching schedule } \\
\text { menu and press searching button }\end{array}$ & $\begin{array}{l}\text { Show the list of travel schedule } \\
\text { that available }\end{array}$ & {$[\checkmark]$ Success[ ] Fail } \\
\hline $\begin{array}{l}\text { 5. Detail of schedule } \\
\text { page }\end{array}$ & $\begin{array}{l}\text { Choose the schedule from the list } \\
\text { of available schedule }\end{array}$ & $\begin{array}{l}\text { Show the time schedule according } \\
\text { to available schedule }\end{array}$ & {$[\checkmark]$ Success[ ] Fail } \\
\hline 6. Seat page & $\begin{array}{l}\text { Choose the detail of available } \\
\text { schedule }\end{array}$ & $\begin{array}{l}\text { Go to seat page and show the list } \\
\text { of reserved seat and available seat }\end{array}$ & {$[\checkmark]$ Success[ ] Fail } \\
\hline \multirow{3}{*}{$\begin{array}{l}\text { 7. Reservation form } \\
\text { page } \\
\text { Confirmation page }\end{array}$} & Choose the available seat & Go to reservation form & {$[\checkmark]$ Success[ ] Fail } \\
\hline & Choose the district & Showing pick up form & {$[\checkmark$ ] Success[ ] Fail } \\
\hline & Choose other district & Show travel address & {$[\checkmark$ ] Success[ ] Fail } \\
\hline $\begin{array}{l}\text { 8. List of } \\
\text { reservation page }\end{array}$ & Press reservation button & $\begin{array}{l}\text { The booking was successful and } \\
\text { returned to the main menu }\end{array}$ & {$[\checkmark]$ Success[ ] Fail } \\
\hline 9. Historical page & $\begin{array}{l}\text { Select the order list menu in the } \\
\text { side menu }\end{array}$ & Displays the list of active orders & {$[\checkmark]$ Success[ ] Fail } \\
\hline 10. Schedule page & $\begin{array}{l}\text { Select the history menu in the } \\
\text { side menu }\end{array}$ & Displays the order history list & {$[\checkmark]$ Success[ ] Fail } \\
\hline
\end{tabular}

Question 3.The RIVAL application is easy to operate.

Table 7. Result of Question 3

\begin{tabular}{llllll}
\hline Question & No & Information & Score & Q & S \\
\hline 3 & 1 & Very easy & 5 & 3 & 15 \\
& 2 & Quite easy & 4 & 5 & 20 \\
& 3 & Neutral & 3 & 0 & 0 \\
& 4 & Quite difficult & 2 & 0 & 0 \\
& 5 & Very difficult & 1 & 0 & 0 \\
\hline Total & & & & $\mathbf{8}$ & $\mathbf{3 5}$ \\
\hline
\end{tabular}

$$
P=\frac{35}{40} x 100 \%=\mathbf{8 7 . 5} \%
$$

Intepretation: RIVAL application is quite easy to operate.

Question 4.The RIVAL application help you to make travel reservation.

Table 8. Result of Question 4

\begin{tabular}{|c|c|c|c|c|c|}
\hline Question & No & Information & Score & $\mathbf{Q}$ & $S$ \\
\hline \multirow[t]{5}{*}{4} & 1 & Very helpful & 5 & 1 & 5 \\
\hline & 2 & Quite helpful & 4 & 7 & 28 \\
\hline & 3 & Neutral & 3 & 0 & 0 \\
\hline & 4 & Unhelpful & 2 & 0 & 0 \\
\hline & 5 & Very unhelpful & 1 & 0 & 0 \\
\hline Total & & & & 8 & 33 \\
\hline
\end{tabular}

Intepretation: the RIVAL application is very helpfull to make travel reservation.
Question 5.Do you find any obstacle or bugs while using RIVAL application?

Table 8. Result of Question 4

\begin{tabular}{llllll}
\hline Question & No & Information & Score & $\mathbf{Q}$ & S \\
\hline \multirow{2}{*}{5} & 1 & Yes & 1 & 1 & 1 \\
& 2 & No & 2 & 7 & 14 \\
\hline Total & & & $\mathbf{8}$ & $\mathbf{1 5}$ \\
\hline \multicolumn{2}{c}{$P=\frac{15}{16} x 100 \%=\mathbf{9 3 . 8} \%$}
\end{tabular}

Intepretation: there is no obstacle or bugs while using RIVAL application.

The results of beta testing have been done by summarizing the results of the questionnaire obtained from eight respondents. It can be concluded that the RIVAL application has met or achieved the desired goals and also obtained constraint responses to the problems of the choice of departure city and destination city that previously used the the Popup menu. Itthen converted to use Alert Dialog, because when using popup menu while the application is accessed using a Smartphone that has a small screen size, the popup menu is almost filled the screen.

\section{CONCLUSION}

The RIVAL (Cari Travel Area Malang) has been designed and developed using the Android 
system as a one-stop application to make travel reservations in the Malang area. The stage of developing the RIVAL application started by designing a flowchart as the business process of RIVAL application, designing the database, UI/UX, system implementation, and testing. The result of testing shows that the RIVAL application work properly and easy to use. Hopefully, in the next stage, we can develop using the IOS system and can develop not only in Malang city.

\section{REFERENCES}

[1] Marr, B. 2016. Why everyone must get ready for the $4^{\text {th }}$ Industrial Revolution. Available at: https://www.forbes.com/sites/bernardmarr/ 2016/04/05/why-everyone-must-get-readyfor-4th-industrial-revolution/\#29d896003f90

[2] Baktha, K. 2017. Mobile application development: all the steps and guidelines for successful creation of mobile app: case study. International Journal of Computer Science and Mobile Computing 6(9), 15-20.

[3] Sahri, I. K. 2017. ICT dan perubahan budaya di Indonesia: kajian atas penggunaan ICT kecenderungan perubahan budaya masyarakat Indonesia. TARBAWI 6(2), 101114.

[4] Purmada, D. K., Wilopo, and L. Hakim. 2016. Pengelolaan desa wisata dalam perspektif community based tourism (studi kasus pada Desa Wisata Gubug Klakah, Kecamatan Poncokusumo, Kabupaten Malang). Jurnal Administrasi Bisnis 32(2), 15-22.

[5] Wibowo, T. S., and I. Pratomo. 2020. Analysis of Malang City readiness in realizing Smart Tourism with new integrated E-Readiness model. 2020 International Conference on Smart Technology and Applications (ICOSTA) IEEE. 1-6.

[6] Nuansa, C., S. Suryadi, and D. Wisadirana. 2014. Designing promotion strategy of Malang Raya's tourism destination branding through audio visual media. Journal of Indonesian Tourism and Development Studies 2(2), 82-85.

[7] Surilansih, P.,B. Supriyono, and $M$. Hadi.2013. Upaya pelaksanaan sinergi kebijakan transportasi sebagai penunjang pengem-bangan potensi pariwisata di Kota Blitar (studi pada Dinas Perhubungan Daerah Kota Blitar dan Dinas Komunikasi). Informatika dan Pariwisata Daerah Kota Blitar. Jurnal Administrasi Publik1(4), 203212.
[8] Similarweb. 2018. The use of websites and applications in the world.Available at: www.similarweb.com.

[9] Shi, M. 2010. Software functional testing from the perspective of business practice computer abd information science. Available at: www.ccssenet.org/cis.

[10] Khan, M. E. 2011. Different approach to blackbox testing technique for finding error. International Journal of Software Enginering and Application 2(4), 31-40.

[11] Mohd,C. K. N., and F. Shabodin.2015. Personalized Learning Environment: Alpha Testing, Beta Testing and User Acceptance Test. World Conference on Technology, Innovation and Entrepreneurship. 